\title{
INFLUENCE OF L-TRYPTOPHAN AND ZINC ASPARTATE ON THE SENSITIVITY OF GRAM-NEGATIVE MICROORGANISMS TO DOXYCYCLINE
}

\section{WPŁYW L-TRYPTOFANU I ASPARAGINIANU CYNKU NA WRAŻLIWOŚĆ DROBNOUSTROJÓW GRAM UJEMNYCH NA DOKSYCYKLINE}

\author{
Tatiana Artyukh ${ }^{1(A, B, C, D, E, F)}$, Tatiana Sokolova ${ }^{1(A, B, E, F)}$ \\ ${ }^{1}$ Department of Microbiology, Virology and Immunology, Grodno State Medical University, Grodno, Belarus
}

Authors' contribution Wkład autorów:

A. Study design/planning zaplanowanie badań B. Data collection/entry zebranie danych C. Data analysis/statistics dane - analiza i statystyki D. Data interpretation interpretacja danych E. Preparation of manuscript przygotowanie artykułu F. Literature analysis/search wyszukiwanie i analiza literatury G. Funds collection zebranie funduszy
Tables: 2

Figures: 3

References: 27

Submitted: $2021 \mathrm{Jul} 5$

Accepted: 2021 Aug 23

\section{Summary}

Background. With an increase in antibiotic resistance in microorganisms, increasing the effectiveness of antibiotic therapy has become a crucial task for medical and pharmaceutical sciences. One possible way to increase the effectiveness of antibiotic therapy is to monitor biologically active substances like amino acids for their capability of increasing the activity of antibiotics. This research aimed to study the effects of tryptophan and zinc aspartate on the activity of doxycycline in relation to E. coli and P. aeruginosa.

Material and methods. The in vitro serial dilution method was used to determine the minimum inhibitory concentration (MIC) of doxycycline independently and in combination with tryptophan and zinc aspartate, for E. coli and P. aeruginosa.

Results. Tryptophan and zinc aspartate at a concentration of $2 \mu \mathrm{g} / \mathrm{ml}$ significantly increased the antibiotic activity of doxycycline against $E$. coli and P. aeruginosa $(\mathrm{p}<0.0001)$.

Conclusions. Biologically active substances, tryptophan and zinc aspartate have a modulating effect on the antibiotic sensitivity of microorganisms towards antibacterial drugs like doxycycline.

Keywords: zinc aspartate, doxycycline, minimum inhibitory concentration, tryptophan, antibiotic resistance

\section{Streszczenie}

Wprowadzenie. Zwiększenie skuteczności antybiotykoterapii w obliczu narastającej oporności drobnoustrojów na antybiotyki jest ważnym zadaniem nauk medycznych i farmaceutycznych. Jednym z możliwych sposobów jest monitorowanie substancji biologicznie czynnych, w tym aminokwasów, jako substancji mogących zwiększać aktywność antybiotyków. Celem pracy było zbadanie wpływu tryptofanu i asparaginianu cynku na aktywność doksycykliny w stosunku do E. coli oraz P. aeruginosa.

Materiał i metody. Została wykorzystana metoda seryjnych rozcieńczeń in vitro w celu określenia minimalnego stężenia hamującego (minimum inhibitory concentration - MIC) doksycykliny oraz doksycykliny w połączeniu z tryptofanem i asparaginianem cynku w stosunku do $E$. coli i $P$. aeruginosa.

Wyniki. Asparaginian cynku i tryptofan w stężeniu $2 \mu \mathrm{g} / \mathrm{ml}$ zwiększył istotnie aktywność antybiotyczną doksycykliny wobec $E$. coli i $P$. aeruginosa $(\mathrm{p}<0.0001)$.

Wnioski. Substancje biologicznie czynne (tryptofan i asparaginian cynku) mają modulujący wpływ na wrażliwość mikroorganizmów na leki antybakteryjne, takie jak doksycyklina.

Słowa kluczowe: asparaginian cynku, doksycyklina, minimalne stężenie hamujące, tryptofan, antybiotykooporność

Address for correspondence / Adres korespondencyjny: Tatiana Artyukh, Department of Microbiology, Virology and Immunology, Grodno State Medical University, Ulitsa Maksima Gor'kogo 80, Grodno 230009, Belarus, e-mail: taniaartsiukh@gmail.com, phone: +375 152443652

ORCID: Tatiana Artyukh https://orcid.org/0000-0001-7368-0623, Tatiana Sokolova https://orcid.org/0000-0002-4075-4515

Copyright: (C) Pope John Paul II State School of Higher Education in Biała Podlaska, Tatiana Artyukh, Tatiana Sokolova. This is an Open Access journal, all articles are distributed under the terms of the Creative Commons Attribution-NonCommercial-ShareAlike 4.0 International (CC BY-NC-SA 4.0) License (http://creativecommons.org/licenses/by-nc-sa/4.0/), allowing third parties to copy and redistribute the material in any medium or format and to remix, transform, and build upon the material, provided the original work is properly cited and states its license. 


\section{Introduction}

One of the main reasons for the chronicity and recurrence of infectious diseases is the ineffectiveness of antibiotic therapy due to the spread of antibiotic-resistant strains of microorganisms [1,2]. Antibiotic resistance is a global problem that poses a serious health and economic risks [3]. The main events in the spread of antibiotic resistance are - bacteria becoming a host of resistance genes, transfer of antibiotic resistance to other bacteria by horizontal gene transfer, and migration of antibiotic resistance in the environment [4].

It is known, that most microorganisms in natural habitats exist in the biofilm and that the level of horizontal gene transfer between representatives of the biofilm community is higher than between planktonic cells [5]. For the treatment of infections associated with microbial biofilms, up to 100 times larger doses of antibiotics are required, which renders the drug ineffective due to toxicity to the microorganism [6,7]. Exposure to microorganisms in a biofilm with a concentration insufficient to eliminate all biofilm representatives from the body increases resistance through the inclusion of genetic programs (quorum sensing, QS and cyclic di-guanosine monophosphate, c-di-GMP) [8]. As a result, a high degree of coordination of gene expression and adaptation mechanisms is achieved, including the inclusion of acquired resistance of microorganisms to antibacterial drugs $[9,10]$.

For this reason, monitoring of substances that increase the effectiveness of antibiotic therapy, while not aggravating the negative effect of antibiotics on the human body, is relevant. Some biologically active substances (BAS) can increase the effectiveness of antibodies. Tryptophan and zinc aspartate are organic compounds that play a key role in all living organisms. Amino acids determine protein biosynthesis and neurotransmitter transport [11]. Zinc is also a unique trace element with bactericidal properties [12].

BAS can affect the vital activity of bacteria as independent substances, as well as in combination with antibacterial drugs in in vitro studies. The ability of tryptophan to prevent the development and to cause dispersion of biofilms of $P$. aeruginosa bacteria, has been established [13]. The ability of $C$. copticum extract with five active compounds to inhibit pathogenic bacteria in planktonic form was confirmed using the disk diffusion tests (MIC and MBC) [14].

Microorganisms and human cells metabolize carbohydrates and amino acids in a similar fashion into equivalent products [15]. Due to this similarity in metabolism the carbohydrates and amino acids can be used as adjuvants/fillers for drugs to help enhance their antibacterial properties. Aspartic and glutamic acid increases the activity of the antibiotic trimethoprim by the formation of novel salts of trimethoprim. The formation of these salts retained antibacterial activity and also exhibited a higher zone of inhibition of $E$. coli due to the improved solubility of trimethoprim [16]. Similarly, the solubility of indomethacin is also enhanced by salt formation using the basic amino acids L-arginine and L-lysine as counterions [17]. The resulting salts have better solubility, increased absorption, and therefore, greater efficiency.

The therapeutic effect of biologically active substances can be realized by multiple mechanisms: through blocking the synthesis of cellular elements, can be directed to the mechanisms of initial adhesion of bacteria to the surface, blocking the synthesis or destruction of the polymer matrix, disruption of intercellular information exchange, and it can also be combined with bactericidal agents themselves [18,19]. The use of biologically active substances as substances that increase the activity of antibiotic therapy, not only leads to better clinical results but also provides a tool for combating antimicrobial resistance. This study investigates the effect of tryptophan and zinc aspartate on the antibacterial properties of doxycycline.

\section{Material and methods}

The study was carried out on strains E. coli 2646 and P. aeruginosa 2745. The minimum inhibitory concentration (MIC) was determined for the following drug and BAS combinations: group 1 - doxycycline (DOX) at a concentration $(200-2 \mu \mathrm{g} / \mathrm{ml})$; group $2-$ doxycycline $(200-2 \mu \mathrm{g} / \mathrm{ml})$ and tryptophan $(200-2 \mu \mathrm{g} / \mathrm{ml})$; group 3 - doxycycline $(200-2 \mu \mathrm{g} / \mathrm{ml})$ and zinc aspartate $(200-2 \mu \mathrm{g} / \mathrm{ml})$; group $4-$ doxycycline $(200-2 \mu \mathrm{g} / \mathrm{ml})$ and a mixture (tryptophan $(200-2 \mu \mathrm{g} / \mathrm{ml})$ and zinc aspartate $(200-2 \mu \mathrm{g} / \mathrm{ml}$ ) (Figure 1). Bacterial cell concentration in the growth media was measured using a densitometer, Den-1 (Biosan). 


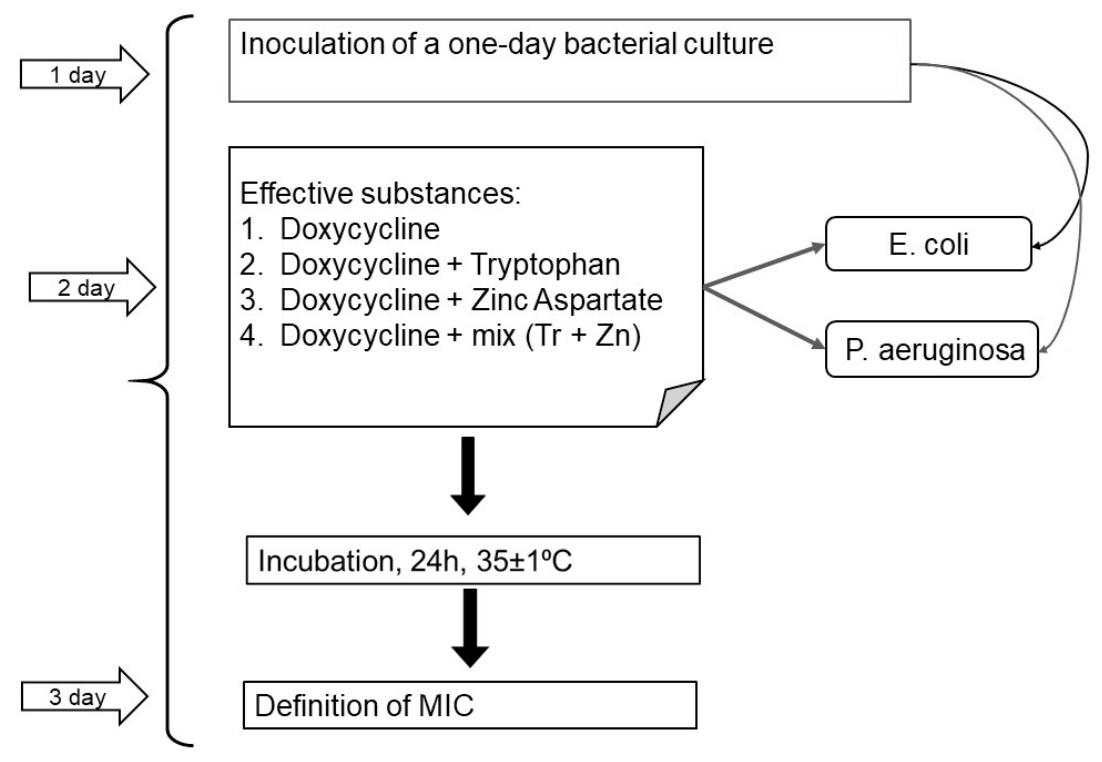

Figure 1. Schematic layout of the experiment $(n=5)$

Bacterial cultures were adjusted to a concentration of $1.5 \times 10^{8} \mathrm{CFU} / \mathrm{ml}$ unit. (0.5 McFarland units) in sterile saline sodium chloride solution. Sixteen test tubes were prepared for each microorganism by adding $5 \mathrm{ml}$ of Mueller-Hinton broth and $0.2 \mathrm{ml}$ of inoculum to each tube. Four sets of four test tubes were prepared for each treatment group where one test tube acted as the control without any drug and the remaining three test tubes had tenfold dilutions of the treatment drug and BAS combinations. The concentration of microbial cells was determined by measuring the optical density of solutions on a densitometer before and after 24-hour of incubation at $35 \pm 1^{\circ} \mathrm{C}$ [20]. The experiments were performed in 5 repetitions $(n=5)$ (Figures 2 and 3; Tables 1 and 2). The effect of four groups of drugs on the growth of the planktonic form of bacteria was calculated by a multivariate analysis of variance using Statistica (version 10.0).

The data obtained in the form of McFarland units (McF units) can be interpreted in colony-forming units (CFU) [21].

\section{Results}

Minimum inhibitory concentration (MIC) for each treatment group was determined for $E$. coli and $P$. aeruginosa. The sensitivity of planktonic forms of $E$. coli and $P$. aeruginosa to doxycycline in the presence of tryptophan and zinc aspartate are presented in Figures 2 and 3, respectively.

The minimum inhibitory concentration (MIC) of doxycycline in relation to E. coli was $20 \mu \mathrm{g} / \mathrm{ml}$; MIC of doxycycline with tryptophan in relation to $E$. coli was $200 \mu \mathrm{g} / \mathrm{ml}$; MIC of doxycycline with zinc in relation to E. coli was $200 \mu \mathrm{g} / \mathrm{ml}$. At the same time, as the results of the study showed, at doxycycline concentration of $2 \mu \mathrm{g} / \mathrm{ml}$ the bacterial growth of E. coli was $1.28[1.16 ; 1.40]$ unit $\mathrm{McF}(\mathrm{p}<0.0001)$ in comparison with the bacterial growth in control at 2.3 units McF ( $\mathrm{p}<0.0001)$. When exposed to a combination of doxycycline $2 \mu \mathrm{g} / \mathrm{ml}+$ tryptophan $2 \mu \mathrm{g} / \mathrm{ml}$ the bacterial growth was $0.42[0.30 ; 0.54]$ unit $\mathrm{McF}(\mathrm{p}<0.0001)$ in comparison with the bacterial growth in control at 2.3 unit McF. When exposed to a combination of doxycycline $2 \mu \mathrm{g} / \mathrm{ml}+$ zinc aspartate $2 \mu \mathrm{g} / \mathrm{ml}$ the bacterial growth was 0.20 unit $\mathrm{McF}(\mathrm{p}<0.0001)$ in comparison with the bacterial growth in control at 2.3 units McF. When exposed to a combination of doxycycline $2 \mu \mathrm{g} / \mathrm{ml}+$ tryptophan $2 \mu \mathrm{g} / \mathrm{ml}+$ zinc aspartate $2 \mu \mathrm{g} / \mathrm{ml}$ the bacterial growth was 0.28 unit McF $(\mathrm{p}<0.0001)$ in comparison with the bacterial growth in control 2.3 unit McF. The combination of doxycycline + zinc aspartate was most effective at the concentration of $2 \mu \mathrm{g} / \mathrm{ml}$, whereas doxycycline was least effective on E. coli. (Figure 2, Table 1). 


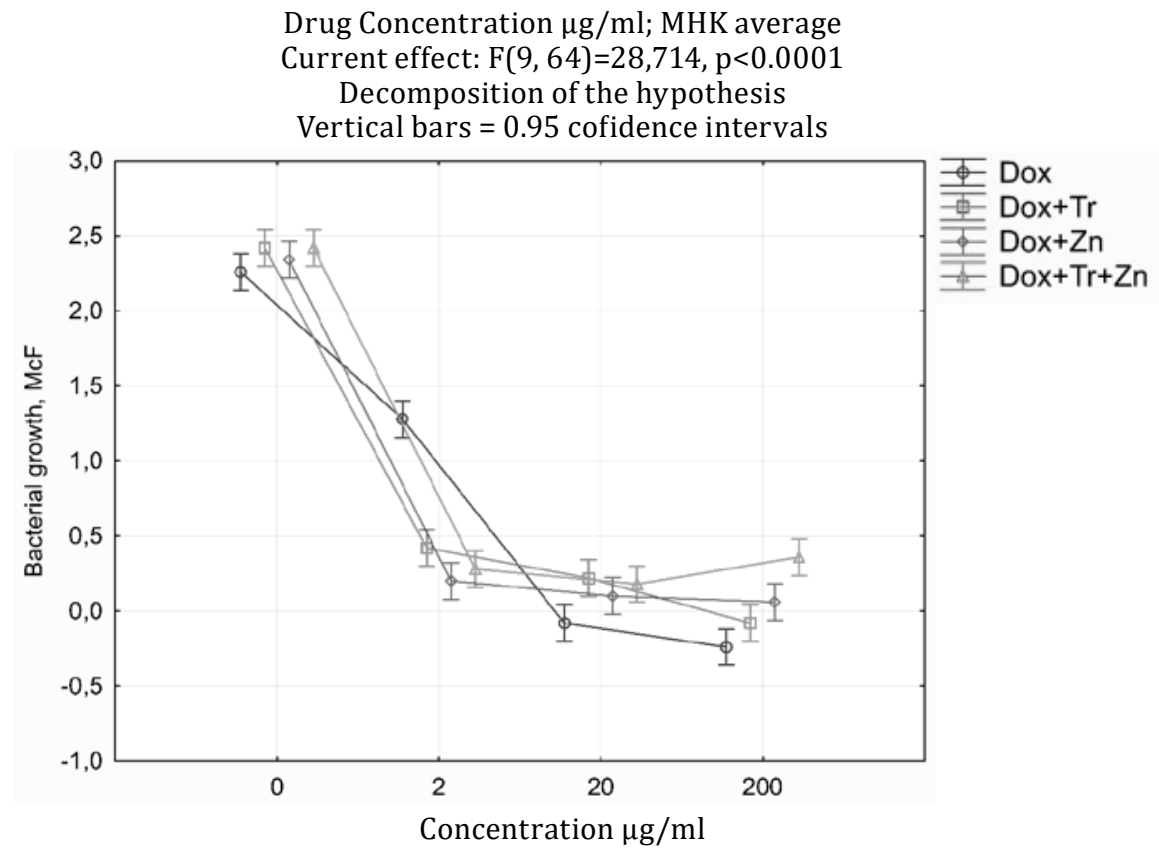

Figure 2. A graph of the dependence of the growth of $E$. coli on the drug and drug concentration

Table 1. Growth rates of $E$. coli when exposed to 4 drugs at a concentration of $2 \mu \mathrm{g} / \mathrm{ml}$ to $200 \mu \mathrm{g} / \mathrm{ml}$

\begin{tabular}{|c|c|c|c|c|c|c|c|}
\hline \multicolumn{8}{|c|}{ Drug Concentration $\mu \mathrm{g} / \mathrm{ml}$} \\
\hline Drug & C & $\begin{array}{l}\text { E. coli } \mathrm{McF} \\
\text { Average }\end{array}$ & $\begin{array}{l}\text { E. coli McF } \\
\text { Standard } \\
\text { error }\end{array}$ & $\begin{array}{c}\text { E. coli } \mathrm{McF} \\
95,00 \%\end{array}$ & $\begin{array}{l}\text { E. coli McF } \\
+95,00 \%\end{array}$ & $\mathbf{n}$ & $\mathbf{p}$ \\
\hline DOX & 0 & 2.26 & 0.06 & 2.14 & 2.38 & 5 & $\mathrm{p}<0.0001$ \\
\hline DOX & 2 & 1.28 & 0.06 & 1.16 & 1.40 & 5 & $\mathrm{p}<0.0001$ \\
\hline DOX & 20 & -0.08 & 0.06 & -0.20 & 0.04 & 5 & $\mathrm{p}<0.0001$ \\
\hline DOX & 200 & -0.24 & 0.06 & -0.36 & -0.12 & 5 & $\mathrm{p}<0.0001$ \\
\hline DOX+Tr & 0 & 2.42 & 0.06 & 2.30 & 2.54 & 5 & $\mathrm{p}<0.0001$ \\
\hline DOX+Tr & 2 & 0.42 & 0.06 & 0.30 & 0.54 & 5 & $\mathrm{p}<0.0001$ \\
\hline DOX+Tr & 20 & 0.22 & 0.06 & 0.10 & 0.34 & 5 & $\mathrm{p}<0.0001$ \\
\hline DOX+Tr & 200 & -0.08 & 0.06 & -0.20 & 0.04 & 5 & $\mathrm{p}<0.0001$ \\
\hline $\mathrm{DOX}+\mathrm{Zn}$ & 0 & 2.34 & 0.06 & 2.22 & 2.46 & 5 & $\mathrm{p}<0.0001$ \\
\hline $\mathrm{DOX}+\mathrm{Zn}$ & 2 & 0.20 & 0.06 & 0.08 & 0.32 & 5 & $\mathrm{p}<0.0001$ \\
\hline $\mathrm{DOX}+\mathrm{Zn}$ & 20 & 0.10 & 0.06 & -0.02 & 0.22 & 5 & $\mathrm{p}<0.0001$ \\
\hline DOX+ Zn & 200 & 0.06 & 0.06 & -0.06 & 0.18 & 5 & $\mathrm{p}<0.0001$ \\
\hline $\mathrm{DOX}+\mathrm{Tr}+\mathrm{Zn}$ & 0 & 2.42 & 0.06 & 2.30 & 2.54 & 5 & $\mathrm{p}<0.0001$ \\
\hline $\mathrm{DOX}+\mathrm{Tr}+\mathrm{Zn}$ & 2 & 0.28 & 0.06 & 0.16 & 0.40 & 5 & $\mathrm{p}<0.0001$ \\
\hline $\mathrm{DOX}+\mathrm{Tr}+\mathrm{Zn}$ & 20 & 0.18 & 0.06 & 0.06 & 0.30 & 5 & $\mathrm{p}<0.0001$ \\
\hline $\mathrm{DOX}+\mathrm{Tr}+\mathrm{Zn}$ & 200 & 0.36 & 0.06 & 0.24 & 0.48 & 5 & $\mathrm{p}<0.0001$ \\
\hline
\end{tabular}

The minimum inhibitory concentration (MIC) of doxycycline in relation to P. aeruginosa was $100 \mu \mathrm{g} / \mathrm{ml} ; \mathrm{with}$ tryptophan was $\geq 200 \mu \mathrm{g} / \mathrm{ml}$; and with zinc was $\geq 200 \mu \mathrm{g} / \mathrm{ml}$.

An increase in the effectiveness of doxycycline in relation to P. aeruginosa is observed in combination with $2 \mu \mathrm{g} / \mathrm{ml}$ of tryptophan and zinc aspartate. When exposed to doxycycline $2 \mu \mathrm{g} / \mathrm{ml}$, the bacterial growth of P. aeruginosa was 4.26 [4.10; 4.42] unit McF. When exposed to a combination of doxycycline $2 \mu \mathrm{g} / \mathrm{ml}+$ tryptophan $2 \mu \mathrm{g} / \mathrm{ml}$ the bacterial growth was 3.54 [3.38; 3.70] unit McF. When exposed to a combination of doxycycline $2 \mu \mathrm{g} / \mathrm{ml}+$ zinc aspartate $2 \mu \mathrm{g} / \mathrm{ml}$ bacterial growth was 3.54 [3.38; 3.70] unit McF. When exposed to a combination of doxycycline $2 \mu \mathrm{g} / \mathrm{ml}+$ tryptophan $2 \mu \mathrm{g} / \mathrm{ml}+$ zinc aspartate $2 \mu \mathrm{g} / \mathrm{ml}$ bacterial growth was 3.66 [3.50; 3.82] unit $\mathrm{McF}$ versus the bacterial growth in control at 3.10 units $\mathrm{McF}(\mathrm{p}<0.0001)$. At a given concentration of drugs $(2 \mu \mathrm{g} / \mathrm{ml})$, the growth rate of bacteria under the action of doxycycline has the greatest difference 4.26 from the combination of doxycycline + zinc aspartate and doxycycline + tryptophan 3.54 (Figure 3, Table 2). 
Drug Concentration $\mu \mathrm{g} / \mathrm{ml}$; MHK average Current effect: $F(9,64)=171,39, p<0.0001$

Decomposition of the hypothesis

Vertical bars $=0.95$ cofidence intervals

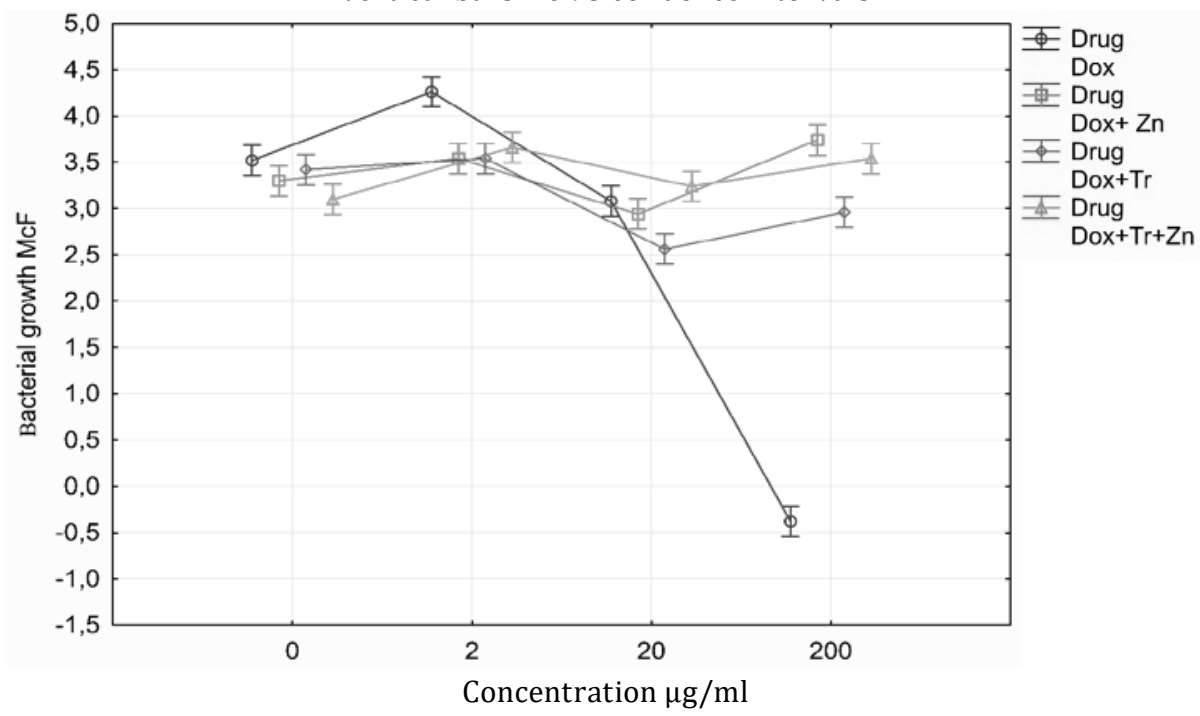

Figure 3. A graph of the dependence of the growth of P. aeruginosa on the drug and drug concentration

Table 2. Growth parameters of P. aeruginosa when exposed to 4 drugs at a concentration of 2-200 $\mu \mathrm{g} / \mathrm{ml}$

\begin{tabular}{|c|c|c|c|c|c|c|c|}
\hline \multicolumn{8}{|c|}{ Drug Concentration $\mu \mathrm{g} / \mathrm{ml}$} \\
\hline Drug & C & $\begin{array}{l}\text { P. aeruginosa } \\
\text { McF Average }\end{array}$ & $\begin{array}{c}\text { P. aeruginosa } \\
\text { McF Standard } \\
\text { error }\end{array}$ & $\begin{array}{l}\text { P. aeruginosa } \\
\text { McF }-95,00 \%\end{array}$ & $\begin{array}{c}\text { P. aeruginosa } \\
\text { McF - } \\
+95,00 \%\end{array}$ & $\mathbf{n}$ & $\mathbf{p}$ \\
\hline DOX & 0 & 3.52 & 0.08 & 3.36 & 3.68 & 5 & $\mathrm{p}<0.0001$ \\
\hline DOX & 2 & 4.26 & 0.08 & 4.10 & 4.42 & 5 & $\mathrm{p}<0.0001$ \\
\hline DOX & 20 & 3.08 & 0.08 & 2.92 & 3.24 & 5 & $\mathrm{p}<0.0001$ \\
\hline DOX & 200 & -0.38 & 0.08 & -0.54 & -0.22 & 5 & $\mathrm{p}<0.0001$ \\
\hline DOX+Tr & 0 & 3.42 & 0.08 & 3.26 & 3.58 & 5 & $\mathrm{p}<0.0001$ \\
\hline DOX+Tr & 2 & 3.54 & 0.08 & 3.38 & 3.70 & 5 & $\mathrm{p}<0.0001$ \\
\hline $\mathrm{DOX}+\mathrm{Tr}$ & 20 & 2.56 & 0.08 & 2.40 & 2.72 & 5 & $\mathrm{p}<0.0001$ \\
\hline $\mathrm{DOX}+\mathrm{Tr}$ & 200 & 2.96 & 0.08 & 2.80 & 3.12 & 5 & $\mathrm{p}<0.0001$ \\
\hline $\mathrm{DOX}+\mathrm{Zn}$ & 0 & 3.30 & 0.08 & 3.14 & 3.46 & 5 & $\mathrm{p}<0.0001$ \\
\hline $\mathrm{DOX}+\mathrm{Zn}$ & 2 & 3.54 & 0.08 & 3.38 & 3.70 & 5 & $\mathrm{p}<0.0001$ \\
\hline $\mathrm{DOX}+\mathrm{Zn}$ & 20 & 2.94 & 0.08 & 2.78 & 3.10 & 5 & $\mathrm{p}<0.0001$ \\
\hline DOX+ Zn & 200 & 3.74 & 0.08 & 3.58 & 3.90 & 5 & $\mathrm{p}<0.0001$ \\
\hline $\mathrm{DOX}+\mathrm{Tr}+\mathrm{Zn}$ & 0 & 3.10 & 0.08 & 2.94 & 3.26 & 5 & $\mathrm{p}<0.0001$ \\
\hline $\mathrm{DOX}+\mathrm{Tr}+\mathrm{Zn}$ & 2 & 3.66 & 0.08 & 3.50 & 3.82 & 5 & $\mathrm{p}<0.0001$ \\
\hline $\mathrm{DOX}+\mathrm{Tr}+\mathrm{Zn}$ & 20 & 3.24 & 0.08 & 3.08 & 3.40 & 5 & $\mathrm{p}<0.0001$ \\
\hline $\mathrm{DOX}+\mathrm{Tr}+\mathrm{Zn}$ & 200 & 3.54 & 0.08 & 3.38 & 3.70 & 5 & $\mathrm{p}<0.0001$ \\
\hline
\end{tabular}

\section{Discussion}

It is known that some antibiotics can stimulate the growth of microorganisms in low concentrations [22]. We observed the same in our experiment, when P. aeruginosa was exposed to doxycycline at a concentration of $2 \mu \mathrm{g} / \mathrm{ml}$, the number of $P$. aeruginosa cells increased, and the turbidity of the inoculum was 4.26 unit McF, greater than in the control without influencing substances the values were 3.6 unit McF.

It should be noted that tryptophan and zinc aspartate have a modulating effect on the activity of doxycycline in all tested concentrations of $2 \mu \mathrm{g} / \mathrm{ml}-200 \mu \mathrm{g} / \mathrm{ml}$, however, the most pronounced effect of tryptophan and zinc aspartate in increasing the activity of doxycycline for $E$. coli was observed at a concentration of $2 \mu \mathrm{g} / \mathrm{ml}$, but at an increase in the concentration of the test substances $20 \mu \mathrm{g} / \mathrm{ml}-200 \mu \mathrm{g} / \mathrm{ml}$, the opposite effect is observed (a slight decrease in the activity of doxycycline). 
It should also be noted that the most pronounced effect of increasing the activity of doxycycline when exposed to tryptophan and zinc was observed in relation to E. coli. Bacterial growth is delayed by 1.08 units McF, when $2 \mu \mathrm{g} / \mathrm{ml}$ zinc aspartate and by 0.86 units $\mathrm{McF}$ when $2 \mu \mathrm{g} / \mathrm{ml}$ tryptophan were added to the medium ( $<<0.0001)$. In relation to $P$. aeruginosa by 0.72 units $\mathrm{McF}$, the value is the same for the two components (zinc aspartate and tryptophan at $2 \mu \mathrm{g} / \mathrm{ml}$ ).

The synergistic effects of tryptophan with zinc aspartate when exposed to non-pathogenic strains of $E$. coli 2646 and $P$. aeruginosa 2745 are not observed in any of the studied concentrations $(2-200 \mu \mathrm{g} / \mathrm{ml})$.

The most important determinants of resistance of gram-negative microorganisms are the constituents of the cell wall, however, many additional factors regarding in vitro cultivation are acquired by bacteria depending on the composition of the nutrient medium [23].

Currently, biologically active substances, including amino acids, are considered as components of the bacterial cell wall, which reflects their control over various forms of the existence of microorganisms (planktonic and biofilm) [24]. Bacterial peptidoglycan, an important functional element in the biosynthesis of the bacterial cell wall, contains amino acid constituents (tryptophan). In addition, exogenous application of amino acids such as methionine, tryptophan, and phenylalanine, when incorporated into bacterial peptidoglycan, replace L-alanine at position 1 and D-alanine at positions 4 and 5 at the terminal position, which leads to bacterial death [25]. Most zinc-containing substances are exploited for their antimicrobial and anti-acne potential as they may represent effective safer alternatives for current treatments with systemic adverse effects [26].

On the one hand, tryptophan and zinc aspartate are necessary for the growth and metabolism of microorganisms, and on the other hand, careful optimization of the composition and concentration of biologically active substances when they are added to the medium can increase the antibacterial effect of antibiotics [27].

\section{Conclusions}

Studies have shown that the introduction of tryptophan and zinc aspartate into the medium at a concentration of $2 \mu \mathrm{g} / \mathrm{ml}-200 \mu \mathrm{g} / \mathrm{ml}$ leads to a change in the sensitivity of the test-microorganisms to doxycycline in the planktonic form.

Further research is needed to study the effect of biologically active substances on the effect of antibiotics with different mechanisms of action and in relation to a wide range of microorganisms to identify the effects of these substances and the principal mode of action.

\section{References:}

1. Bilardi J, Walker S, McNair R, Mooney-Somers J, Temple-Smith M, Bellhouse C, et al. Women's management of recurrent bacterial vaginosis and experiences of clinical care: a qualitative study. PLoS ONE. 2016; 11(3). https://doi.org/10.1371/journal.pone.0151794

2. Magana M, Sereti C, Ioannidis A, Mitchell CA, Ball AR, Magiorkinis E, et al. Options and limitations in clinical investigation of bacterial biofilms. Clin Microbiol Rev. 2018; 31(3). https://doi.org/10.1128/CMR.00084-16

3. Kooi K, Leenstra T, Monen J, Wagenaar I, Woudt S. Antimicrobial resistance surveillance in Central Asia and Europe: practical guide. Geneva: World Health Organization; 2019.

4. Lin Z, Yuan T, Zhou L, Cheng S, Qu X, Luet P, et al. Impact factors of the accumulation, migration and spread of antibiotic resistance in the environment. Environ Geochem Health. 2021; 43(5): 1741-1758. https://doi.org/10.1007/s10653-020-00759-0

5. Petrova 0, Sauer K. Escaping the biofilm in more than one way: desorption, detachment or dispersion. Curr Opin Microbiol. 2016; 30: 67-78. https://doi.org/10.1016/j.mib.2016.01.004

6. Uruén C,Chopo-Escuin G, Tommassen J, Mainar-Jaime RC, Arenas J. Biofilms as promoters of bacterial antibiotic resistance and tolerance. Antibiotics (Basel). 2020; 10(1): 3. https://doi.org/10.3390/antibiotics10010003

7. Artyukh TV, Sokolova TN, Ostrovskaya OB. [Resistance features of E. coli and C. albicans clinical isolates forming a biofilm]. VSMU. 2021; 20(1): 46-54 (in Russian). https://doi.org/10.22263/2312-4156.2021.1.46

8. Zhang LJ, Yu SB, Li WG, Wen-Zhu Z, Yuan W, Jin-Xing L, et al. Polymorphism analysis of virulence-related genes among Candida tropicalis isolates. Chin Med J. 2019; 132(4): 446-453. https://doi.org/10.1097/CM9.0000000000000069

9. Yadav P, Verma S, Bauer R, Kumari M, Dua M, Johri AK, et al. Deciphering streptococcal biofilms. Microorganisms. 2020; 8(11): 1835. https://doi.org/10.3390/microorganisms8111835

10. Urwin L, Okurowska K, Crowther G, Roy S, Garg P, Karunakaran E, et al. Corneal infection models: tools to investigate the role of biofilms in bacterial keratitis. Cells. 2020; 9(11): 2450.

https://doi.org/10.3390/cells9112450 
11. Castro-Portuguez R, Sutphin GL. Kynurenine pathway, NAD+ synthesis, and mitochondrial function: targeting tryptophan metabolism to promote longevity and healthspan. Exp Gerontol. 2020; 132 : 110841. https://doi.org/10.1016/j.exger.2020.110841

12. Presnyakova M, Kostina O, Albitskaya G. The biological role of zinc and its significance in the pathogenesis of autistic disorders. FGBOU VO. 2019; 29(3): 63-70.

13. Abaturov AE, Kryuchko TA. Medication effect on the biofilm dispersion. Amino acids and their derivatives. Childs Health. 2019; 14(8): 490-495. https://doi.org/10.22141/2224-0551.14.8.2019.190844

14. Mohammadi M, Masoumipour F, Hassanshahian M, Jafarinasab T. Study the antibacterial and antibiofilm activity of Carum copticum against antibiotic-resistant bacteria in planktonic and biofilm forms. Microbial Pathogenesis. 2019; 129: 99-105. https://doi.org/10.1016/j.micpath.2019.02.002

15. Idrees M, Mohammad AR, Karodia N, Rahman A. Multimodal role of amino acids in microbial control and drug development. Antibiotics (Basel). 2020; 9(6): 330. https://doi.org/10.3390/antibiotics9060330

16. Elshaer A, Hanson P, Worthington T, Lambert P, Mohammed AR. Preparation and characterization of amino acids-based trimethoprim salts. Pharmaceutics. 2012; 4(1): 179-196. https://doi.org/10.3390/pharmaceutics4010179

17. López Y, Soto SM. The usefulness of microalgae compounds for preventing biofilm infections. Antibiotics (Basel). 2019; 9(1): 9. https://doi.org/10.3390/antibiotics9010009

18. Beloin C, McDougald D. Speciality grand challenge for "biofilms". Front Cell Infect Microbiol. 2021; 11: 632429. https://doi.org/10.3389/fcimb.2021.632429

19. Gopal R, Kim YG, Lee JH, Lee SK, Chae JD, Son BK, et al. Synergistic effects and antibiofilm properties of chimeric peptides against multidrug-resistant Acinetobacter baumannii strains. Antimicrob Agents Chemother. 2014; 58(3): 1622-1629. https://doi.org/10.1128/AAC.02473-13

20. Tapalskiy DV, Bilskiy IA. Antimicrobial susceptibility testing by broth microdilution method: widely available modification. Clinical Microbiology and Antimicrobial Chemotherapy. 2017; 20(1): 62-67. https://doi.org/10.36488/cmac.2018.1.62-67

21. biosan.lv [Internet]. Riga: Biosan SIA; 2019. User manual: suspension turbidity detector DEN-1 BIOSAN [cited 2021 May 10]. Available from: https://biosan.lv/media/products/files/den-1-den-1b-ru204-0319_D7XD9aA. pdf.

22. Mardanova AM, Kabanov DA, Rudakova NL, Sharipova MR. [Biofilm: Basic principles of organization and research methods. Tutorial]. Kazan: Institute of Fundamental Medicine and Biology, Kazan (Volga) Federal University; 2016. p. 1-42 (in Russian).

23. Behzadi $\mathrm{P}$, Baráth Z, Gajdács M. It's not easy being green: a narrative review on the microbiology, virulence and therapeutic prospects of multidrug-resistant pseudomonas aeruginosa. Antibiotics (Basel). 2021; 10(1): 42. https://doi.org/10.3390/antibiotics10010042

24. Chen X, Thomsen TR, Winkler $\mathrm{H}, \mathrm{Xu}$ Y. Influence of biofilm growth age, media, antibiotic concentration and exposure time on Staphylococcus aureus and Pseudomonas aeruginosa biofilm removal in vitro. BMC Microbiol. 2020; 20(1): 264. https://doi.org/10.1186/s12866-020-01947-9

25. Idrees M, Mohammad AR, Karodia N, Rahman A. Multimodal role of amino acids in microbial control and drug development. Antibiotics (Basel). 2020; 9(6): 330. https://doi.org/10.3390/antibiotics9060330

26. Abendrot M, Płuciennik E, Felczak A, Zawadzka K, Piątczak E, Nowaczyk P, et al. Zinc (II) complexes of amino acids as new active ingredients for anti-acne dermatological preparations. Int J Mol Sci. 2021; 22(4). https://doi.org/10.3390/ijms22041641

27. Lam KN, Alexander M, Turnbaugh PJ. Precision medicine goes microscopic: engineering the microbiome to improve drug outcomes. Cell Host Microbe. 2019; 26(1): 22-34. https://doi.org/10.1016/j.chom.2019.06.011 